\title{
Epidemiological Profile of Road Traffic Accidents in a Sub-Saharan Rural Area: Case of Manono in the Democratic Republic of the Congo
}

\author{
Mizelo Wa Nkumwimba Jean', Kayembe Mashika Anselme1, Kiluba Makiki Synphorien², \\ Kampetenga Tshitenga Serge ${ }^{3}$, Ilunga Kandolo Simon'3, Mwarabu Much'apa Bienfait ${ }^{3}$, \\ Maungulu Matungulu Charles ${ }^{3}$, Kabyla Ilunga Benjamin ${ }^{3,4}$ \\ ${ }^{1}$ High of Medical Technical School, Manono, The Democratic Republic of Congo \\ ${ }^{2}$ Faculty of Political, Administrative and Social Sciences, University of Manono, Manono, The Democratic Republic of Congo \\ ${ }^{3}$ School of Public Health, University of Lubumbashi, Lubumbashi, The Democratic Republic of Congo \\ ${ }^{4}$ Faculty of Medicine, University of Lubumbashi, Lubumbashi, The Democratic Republic of Congo \\ Email: silungak@gmail.com
}

How to cite this paper: Jean, M.W.N., Anselme, K.M., Synphorien, K.M., Serge, K.T., Simon, I.K., Bienfait, M.M., Charles, M.M. and Benjamin, K.I. (2019) Epidemiological Profile of Road Traffic Accidents in a Sub-Saharan Rural Area: Case of Manono in the Democratic Republic of the Congo. Open Access Library Journal, 6: e5851. https://doi.org/10.4236/oalib.1105851

Received: October 14, 2019

Accepted: October 28, 2019

Published: October 31, 2019

Copyright $\odot 2019$ by author(s) and Open Access Library Inc.

This work is licensed under the Creative Commons Attribution International License (CC BY 4.0). http://creativecommons.org/licenses/by/4.0/

\begin{abstract}
Introduction: Road accidents constitute a major public health problem with regard to the costs generated by this phenomenon. Methodology: We conducted a cross-sectional descriptive study of Road traffic accidents in the city of Manono, an urban-rural area, with the aim of understanding this phenomenon in a highly suburbanized environment, characterized by artisanal exploitation of among others lithium, coltan with an increasing flow of urban population as well as the automobile car. Results: We found that most road accidents occurred on the day $51.0 \%$, Sunday and Monday 19.2\%. In $78.8 \%$, drivers were $\geq 18$ years old. Conclusion: It is important that an emphasis be placed on the rules of road safety because road accidents do not spare any environment, be it urban or rural.
\end{abstract}

\section{Subject Areas \\ Public Health}

Keywords

Road Accident, Sub-Saharan Africa, Rural, Manono

\section{Introduction}

Globally, every year, nearly 1.2 million people die as a result of traffic accidents, 
and twenty to fifty million are injured or disabled. It is reported that in high-income countries $65 \%$ of deaths from road accidents are made by vehicle drivers. The situation is different in low-income and middle-income countries where $70 \%$ of deaths reported as a result of road accidents are made up of vulnerable road users (pedestrians, cyclists and motorcyclists). Low-income and middle-income countries account for about $85 \%$ of deaths. Yet these countries only have $48 \%$ of the world's car ownership. If appropriate measures are not adopted by 2030, road accidents are likely to be the fifth largest contributor to the global burden of disease. Overall, it is estimated that US $\$ 518$ billion is spent on road traffic accidents in low-income and middle-income countries [1].

\section{Methodology}

We conducted a cross-sectional descriptive study of road accidents in the Manono administrative territory of the Democratic Republic of the Congo. Manono is a territory of the province of Tanganyika in the Democratic Republic of the Congo. The mining resources of the region have made it reputation.

Our sampling is exhaustive and its size is 52 cases of road traffic accidents recorded from $01 / 01 / 2014$ to $31 / 12 / 2018$ (5 years).

\section{Results}

There were more cases of accidents in April (28.8\%) (Figure I \& Table I).

There were more accidents on Mondays and Sundays ( $10 \%$ for each of these days) (Table II).

Table I. Répartition des accidents selon le jour de la semaine.

\begin{tabular}{ccc}
\hline Day & frequency & Percentage \\
\hline Sunday & 10 & 19.2 \\
Thursday & 5 & 9.6 \\
Monday & 10 & 19.2 \\
Tuesday & 6 & 11.5 \\
Wednesday & 7 & 13.5 \\
Saturday & 6 & 11.5 \\
Friday & 8 & 15.4 \\
Total & 52 & 100.0 \\
\hline
\end{tabular}

Table II. Sociodemographic characteristics, causes of accidents and time of onset.

\begin{tabular}{ccc}
\hline Variable & Frequencies & Percentage \\
\hline Over speed & Cause of the accident $(\mathrm{N}=52)$ & \\
Alcohol & 23 & 25.2 \\
others & 13 & 30.8
\end{tabular}




\section{Continued}

\begin{tabular}{ccc}
\hline & \multicolumn{2}{c}{ Time of the day $(\mathrm{N}=52)$} \\
Day & 27 & 51.9 \\
Night & 25 & 48.1 \\
& Driver' Age $(\mathrm{N}=52)$ & \\
& 11 & 21.2 \\
$<18$ years & 41 & 78.8 \\
$\geq 18$ years & & \\
$\quad$ Age of the victim $(\mathrm{N}=52)$ & 3 & 5.8 \\
$\leq 5 \quad 11$ & 21.2 \\
$6-10$ & 11 & 21.2 \\
$11-15$ & 10 & 19.2 \\
$16-20$ & 17 & 32.7 \\
$>20$ & &
\end{tabular}

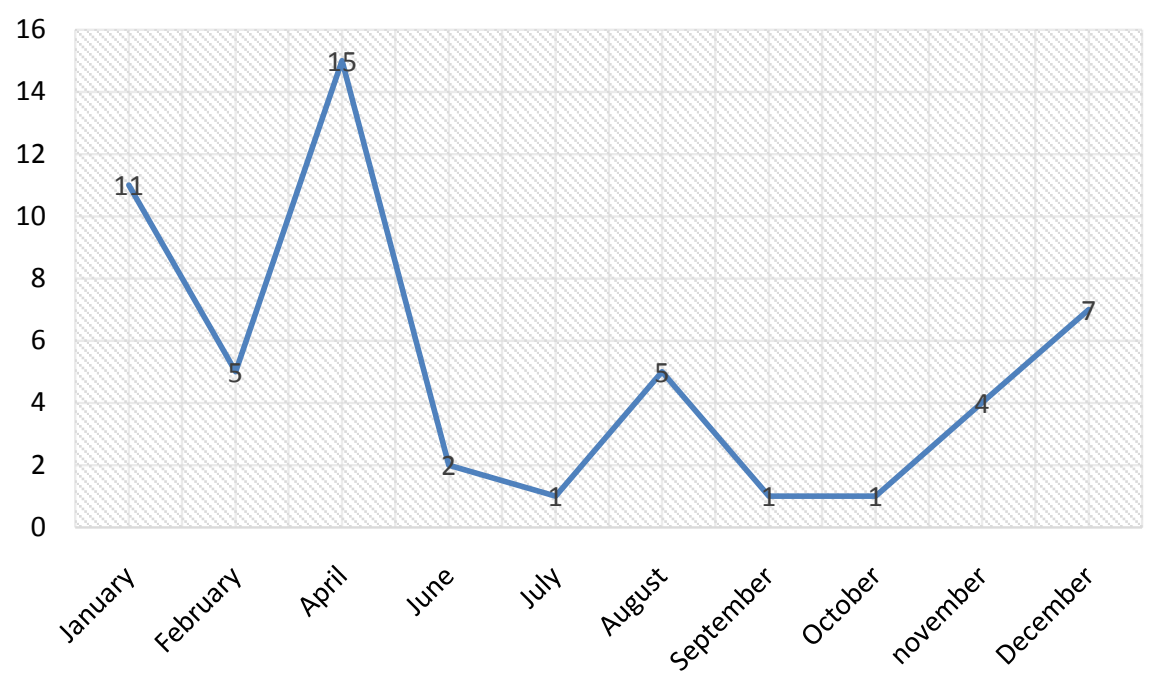

Figure I. Distribution of accidents by month according to occurrence.

The drivers' median age is 22 years $( \pm 5.5)$ while that of victims is 16 years $( \pm 13.7)$.

\section{Discussion}

Figure I shows that in the majority of cases, road accidents occurred in April, followed by January with respectively $28.8 \%$ and $21.2 \%$ while the months of October, September and July recorded few cases of traffic accidents, $1.9 \%$. Our results are different from those found by Ilunga Kandolo Simon [2] in Lubumbashi where the month of November recorded many cases of road accidents (13.0\%). They are also different from those found by Kafando [3] in Burkina Faso where a greater number of traffic accidents were recorded from September. In SaudiArabia [4], specifically in Qassim the monthly distribution of road accidents shows a high rate of road accidents in December while the lowest rate is 
recorded in March with respectively $13.1 \%$ and 5.8\%. Other authors have found that in India the months of May and June had a high rate of road accidents than the other months (94.5\%) [5].

In $10 \%$ of cases, Mondays and Sundays experienced many road accidents (Table I). In Lubumbashi [2], second city of the Democratic Republic of Congo, the last two days of the week (Friday and Saturday) recorded more road accidents than other days of the week with a peak on Saturday is $18.03 \%$ (2011) and $15.98 \%$ (2012). While in Qassim in Saudi Arabia a large number of road accidents on Thursday $15.74 \%$ [4].

Drivers whose age is $\geq 18$ years were more involved in a road accident than those whose age is strictly less than 18 years (Table II) with a median age of 22 years $( \pm 5.5)$. These results are superimposable to those found in Ethiopia [6] as well as in Iran [7] where the predominance of male drivers was also found with respectively $96.9 \%$ and $91.8 \%$.

Most of the victims were in the age groups between 6 and 10 years $(21.2 \%)$ and those aged between 11 and 15 years (21.2\%).

Drunk driving was the main cause involved in the occurrence of road accidents in Manono (44.2\%) followed by other causes (30.8\%) while driving drunkenness came in third with $25 \%$. Our results are superimposable to those of some countries such as Ivory Coast, Arabia, India and Iran, the speeding is the most implicated cause in the occurrence of accidents of road traffic [3] [6] [7] [8] with respectively $31.06 \%, 43.11 \%, 16.3 \%$ and $23.8 \%$. In Nigeria and Ghana, alcohol [10] and fatigue [11] were the causes most involved in the occurrence of road accidents (18.2\% and $36.4 \%)$.

Road accidents were observed more during the day (51.9\%) (Table II). These results are similar to those found in Saudi Arabia, Tanzania and Lubumbashi [2] [4] [12].

\section{Conclusions}

We conducted our study on road accidents in the Manono territory of the Democratic Republic of Congo. We have collected 52 cases of road traffic accidents.

Most accidents occurred on the day (51.9\%), speeding was the main cause (44.2\%).

Victims aged from 6 to 10 years and those aged 11 to 15 were in the majority (21.2\%), with more accidents on Sundays and Mondays (19.9\%). Road accident is a major challenge.

\section{Conflicts of Interest}

The authors declare no conflicts of interest regarding the publication of this paper.

\section{References}

[1] WHO (2009) Global Report on Road Safety. Time for Action. Geneva. 
[2] Kandolo, S.I., et al. (2014) Factors Associated with Road Accidents in the City of Lubumbashi. Sante Publique, 26, 889-895. https://doi.org/10.3917/spub.146.0889

[3] Kafando, Y., Boko, P. and Fournet, F. (2006) Transport urbain et santé des populations: Le cas de Ouagadougou (Burkina Faso). 95.

[4] Barrimah, I., Midhet, F. and Sharaf, F. (2012) Epidemiology of Road Traffic Injuries in Qassim Region, Saudi Arabia: Consistency of Police and Health Data. International Journal of Health Sciences, 6, 31-41. https://doi.org/10.12816/0005971

[5] Mondal, P., Kumar, A., Bhangale, U.D. and Tyagi, D. (2011) A Silent Tsunami on Indian Road: A Comprehensive Analysis of Epidemiological Aspects of Road Traffic Accidents. British Journal of Medicine and Medical Research, 1, 14-23. https://doi.org/10.9734/BJMMR/2011/106

[6] Hassen, A., Godesso, A., Abebe, L. and Girma, E. (2011) Risky Driving Behaviors for Road Traffic Accident among Drivers in Mekele City, Northern Ethiopia. BMC Research Notes, 4, 535. https://doi.org/10.1186/1756-0500-4-535

[7] Moafian, G. and Aghabeigi, M. (2013) An Epidemiologic Survey of Road Traffic Accidents in Iran: Analysis of Driver-Related Factors. Chinese Journal of Traumatology, 16, 140-144.

[8] Manna, N., Mallik, S. and Mandal, P. (2012) Epidemiological Factors of Road Traffic Accidents: A Study in a Tertiary Care Setting in India. Journal of Pakistan Medical Students, 3, 48-53.

[9] Konan, K.J., Assohoun, K.T., Kouassi, F. and Ehua, S.F. (2006) Profil epidemiologique des traumatises de la voie publique aux urgences du chu de yopougon. Revue Internationale des Sciences Médicales d Abidjan, 8, 44-48.

[10] Pepple, G. and Adio, A. (2014) Visual Function of Drivers and Its Relationship to Road Traffic Accidents in Urban Africa. Springerplus, 3, 47.

https://doi.org/10.1186/2193-1801-3-47

[11] Siaw, N.A., Duodu, E. and Kwakye, S. (2012) Trends in Road Traffic Accidents in Ghana; Implications for Improving Road User Safety. International Journal of Humanities and Social Science Invention, 2, 31-35.

[12] Chalya, P.L., Mabula, J.B., Dass, R.M., Mbelenge, N. and Ngayomela, I.H. (2012) Injury Characteristics and Outcome of Road Traffic Crash Victims at Bugando Medical Centre in Northwestern Tanzania. Journal of Trauma Management \& Outcomes, 6, 1. https://doi.org/10.1186/1752-2897-6-1 